\title{
Intensity of soil erosion in Romania, predictions in time and space, European and indigenous perspectives
}

\author{
Petru Cardei ${ }^{1,{ }^{*}}$, Raluca Sfiru ${ }^{1}$, and Vergil Muraru ${ }^{1}$ \\ In memoriam Vasile Herea \\ ${ }^{1}$ INMA Bucharest, Informatics and Engineering, No 6 Bd Ion Ionescu de la Brad Bucharest, Romania
}

\begin{abstract}
The subject of this article is the estimation of the water erosion given by different sources during the history of over one hundred years of observations. The differences between the estimates made at the near times, or at the appreciably different times, are viewed for the approximation, of the random behaviour of the factors involved in the water erosion process, but also for the changes (apparently in time) of the intensity of the factors involved. The so-called climatic changes, characterized mainly by apparently (at the scale of human life) nonperiodic changes of meteorological factors, produce effects including on the factors involved in water erosion, which are not in the category of meteorological parameters, such as soil erodibility, but also the geometric parameters of the slopes. By default, there are effects in vegetal cover and management parameters. From this point of view, the influencing factors of mathematical models for predicting water erosion should be recalculated or periodically reviewed.
\end{abstract}

\section{Introduction}

The idea of writing this article started from the differences of appreciation of the intensity of the water erosion in time and space, which means, from the perspective of the specialists from different geographical areas. It is a definite fact that estimating and forecasting the intensity of soil erosion is a very difficult test for any specialist. Over time, the estimation and the prediction of soil erosion have become more precise, benefiting from a multidisciplinary contribution of unquestionable. However, when we compare the values of the estimates at large intervals, must we consider that today's soil is not the same as fifty or one hundred years ago, and the soil over fifty years will not be the same as today. In this context, in which we are aware the irreversibility of the transformation of the eroded subject (soil) but also of the main erosive factor (climatic conditions) and secondary (man and his habits, however a component of nature) is can be made a comparison between different estimates over time and by different authors. Is trying a possible explanation of the differences in the estimates in time and space (regarding authors from different areas) and,

* Corresponding author: petru cardei@yahoo.com 
by this, some modifications are suggested in the formulation of the mathematical models of erosion, which will, possibly, give them a dynamic character.

Research on soil erosion in Romania has a history of over half a century, [1], [12], and [15]. Results of the researches on the water erosion evolution on the Romanian territory also appear in books containing collections of advanced research in the field, [13-14], [16$18]$.

\section{Estimates and measurements of the intensity of water erosion in Romania}

Estimating the intensity of erosion has been a permanent concern in the world of science since the beginning of the 20th century. A beautiful fresco of the history of the development of the scientific field of soil erosion is presented in [11]. Now, after more than a hundred years from the beginning, it is tempting to compare the estimates made in the same geographical area, at different times and with different tools, which are becoming more and more refined. Such tests are possible for many geographical areas. I will limit myself to the one they belong to, for now, Romania.

\section{Results}

To benefit from several sources of erosion estimation, we restricted the analysis to the territory of Romania, where I participated in 2005 - 2012 in some research projects that had as a subject the water erosion of the soil. For simplicity, we will present the results found in the temporal order.

In [1], page 92, table 8, it is shown that at the level of the years $1950-1960$, the annual loss of soil by erosion in the Valea Calugareasca wine-growing area was $172.90 \mathrm{t} / \mathrm{ha}$, for lands with a $25 \%$ slope, without anti-erosion land management. It is remarkable that, at that time, the author separates the losses by seasons (December-March, 0 t/ha, April-May, 96.0 t/ha, June-September, $76.0 \mathrm{t} / \mathrm{ha}$ and October-November, $0.900 \mathrm{t} / \mathrm{ha}$ ).

An estimate of water erosion since 1983, [2], indicates for the above area an average value of 30-45 t/ha per year.

In a research project dedicated to the study of water erosion and landslides, we estimated the risk of erosion and represented as a map this parameter for the entire territory of the Research Institute for Vine and Viticulture, ICDVV Valea Calugareasca from Prahova county. We have presented the results in [3] as a risk map of water erosion resulting from the research. The values of the risk of water erosion indicated by the map in [3] are between 0 and 30 t/ha per year. However, 48,205\% of the mapped area has soil losses through water erosion below $3 \mathrm{t} /$ ha per year and less than $22 \%$ have soil losses through water erosion of over $7 \mathrm{t} / \mathrm{ha}$ per year. These statistical conclusions can be seen in fig. 1. For the calculation the USLE mathematical model was used and applied to each vineyard plots, including for the plots which at the time were not cultivated, having only uncontrolled plant cover. For the calculation, each plot was considered as a whole slope surface with constant inclination. The slope and inclination were determined on the images from the Google Earth archive, so the approximation is coarse. 


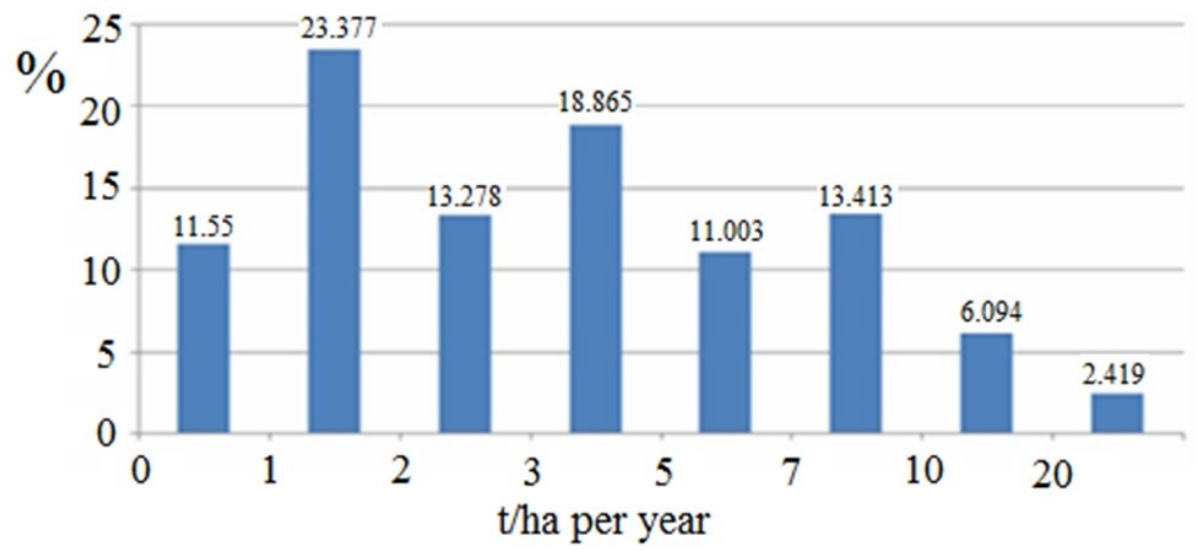

Fig. 1 Distribution of vineyards plots by risk intervals of water erosion, in the territory of the ICDVV Valea Calugareasca.

Using the ESDAC databases, the average assessment of water erosion at the county level in Romania can be extracted (data valid for micro-regions and in the EU). From the Excel public data files extracted from the ESDAC ${ }^{\dagger}$ address, [4-6], the synthetic representation of erosion in Romania can be obtained, table 1. For Prahova county, we have the soil value lost through water erosion of $2.45 \mathrm{t} /$ ha per year.

Table 1. Counties of Romania in order of average value of soil loss through water erosion, in $\mathrm{t} / \mathrm{ha}$ per year.

\begin{tabular}{|l|l|l|l|l|l|}
\hline Vaslui & 7.75 & Neamt & 2.75 & Arges & 2.09 \\
\hline Iasi & 5.97 & Hunedoara & 2.73 & Tulcea & 1.95 \\
\hline Botosani & 5.92 & Harghita & 2.72 & Olt & 1.79 \\
\hline Cluj & 5.26 & Suceava & 2.59 & Covasna & 1.66 \\
\hline Salaj & 5.00 & Valcea & 2.55 & Timis & 1.63 \\
\hline Mures & 4.72 & Prahova & 2.45 & Dambovita & 1.51 \\
\hline Bistrita-Nasaud & 4.30 & Satu Mare & 2.42 & Arad & 1.51 \\
\hline Bacau & 4.20 & Buzau & 2.41 & Teleorman & 1.29 \\
\hline Galati & 4.09 & Caras-Severin & 2.37 & Bucuresti & 1.13 \\
\hline Alba & 3.96 & Constanta & 2.32 & Ilfov & 1.07 \\
\hline Sibiu & 3.57 & Brasov & 2.31 & Giurgiu & 1.06 \\
\hline Mehedinti & 3.12 & Dolj & 2.22 & Calarasi & 1.02 \\
\hline Maramures & 2.95 & Gorj & 2.22 & Ialomita & 0.93 \\
\hline Bihor & 2.79 & Vrancea & 2.20 & Braila & 0.84 \\
\hline
\end{tabular}

The problem of the relatively large differences between the presented estimates is not so much one of an order of magnitude, but rather one that is related to the dynamics of the erosion process, the dynamics of the components involved in the process: the climatic factor, but can, especially, the soil evolution (structure, texture, composition). The differences can be seen in fig. 2. The assessments given in the presented documents are in agreement with [7], the SIDASS project.

An obvious observation, which results from the ranking given in fig. 3 or table 1 , refers to the fact that compared to the hierarchies of the 1950s, 1980s, where the counties of Vrancea and Buzau were the first, in the ESDAC map, the 2015 edition, they are halfway ranking.

\footnotetext{
$\dagger$ The resolution of public maps based on ESDAC is insufficient to estimate the intensity of erosion on the slopes of a normal farm. They are for guidance only.
} 
For example, compared to the 1983 estimate, [2], the values of the ESDAC map are approximately 7 times lower, relative to the maximum value.

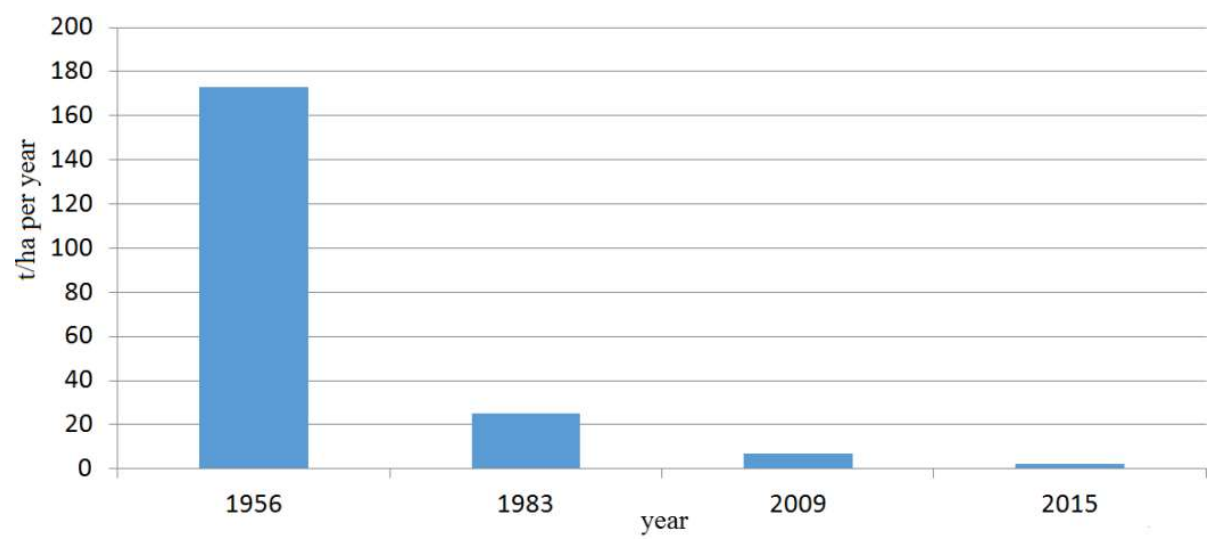

Fig. 2 A dynamic image of soil loss estimates by water erosion in the Valea Calugareasca winegrowing area, Prahova county, Romania.

The problem of the relatively large differences between the presented estimates is not so much one of an order of magnitude, but rather one that relates to the dynamics of the erosion process, the dynamics of the components involved in the process: the climatic factor, but may, in particular, the soil evolution (structure, texture, composition). The differences can be seen in fig. 2. The data appraisals in the documents presented are in agreement with [7], the SIDASS project.

The problem of estimating the intensity of erosion extends to the whole country, Romania. Using the data from table 1, the graphical representation of fig. 3 is obtained, which facilitates easier observation of the ranking of counties after soil loss through erosion.

In 2009, as part of a research project in the field of soil erosion and landslides, we tested for the Valea Calugareasca wine area, a somewhat new mathematical model, [8]. The mathematical model [8], of empirical type, is a linear model of the sum of effects type (unlike USLE, which is a factorial model):

$$
A=41.73+0.181 \cdot p+0.046 \cdot I-0.387 \cdot \text { clay }-8.125 \cdot \text { aveg }
$$

where:

- $p$ is the slope in percentages;

- $I$ is the amount of annual precipitation, in $\mathrm{cm}$;

- clay is the percentage of clay contained in the soil;

- aveg is a coefficient of vegetal cover established by the authors [1], as follows: 1, for soil not covered and ploughed, 2 for partially covered soil in a proportion of maximum $25 \%, 3$, for a cover between 25 and $50 \%$, 4, for the vegetation of forest type between 50 and $75 \%$ and 5 , for very dense vegetation;

- $A$ is the annual loss of soil in tonnes per hectare.

For the Valea Calugareasca area, the clay content in the soil, according to [9], varies between 9 and $43 \%$. Also from [9] is obtain the multiannual average precipitation for the years $2000-2012$ is $660.8 \mathrm{~mm}$, respectively $604.7 \mathrm{~mm}$, the annual average. The slopes of agricultural land (wine-growing area) in Valea Calugareasca are between $8 \%$ and $30 \%$, according to [10]. 
It can be seen that the simple formula proposed by the authors [8], leads to results that fit well with the erosion intensity estimates in the Valea Calugareasca area without a recalculation of the coefficients of formula (1) with the help of experimental results.

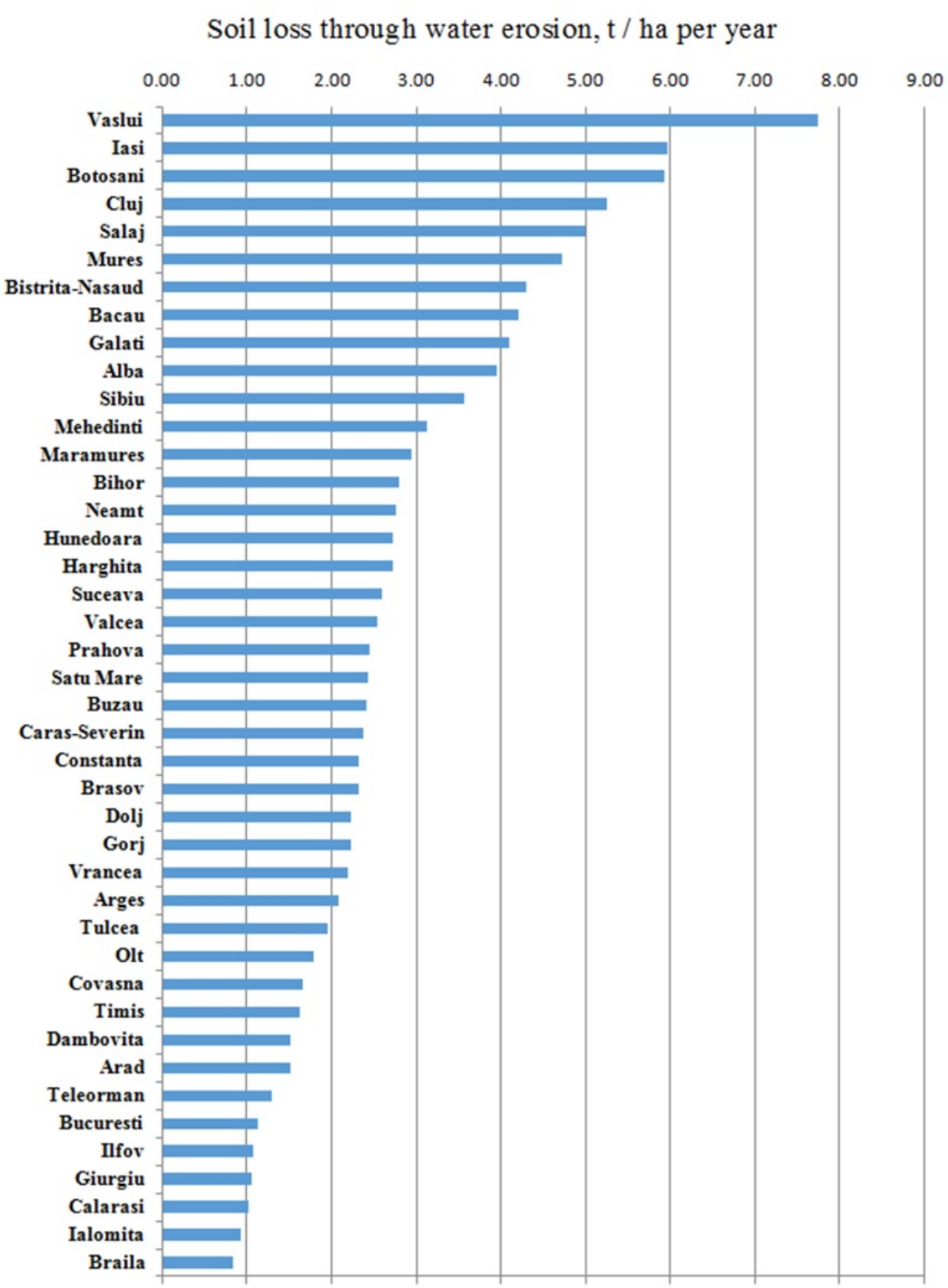

Fig. 3 Graphic representation for the hierarchy of water erosion at the county level in Romania, [7]. 


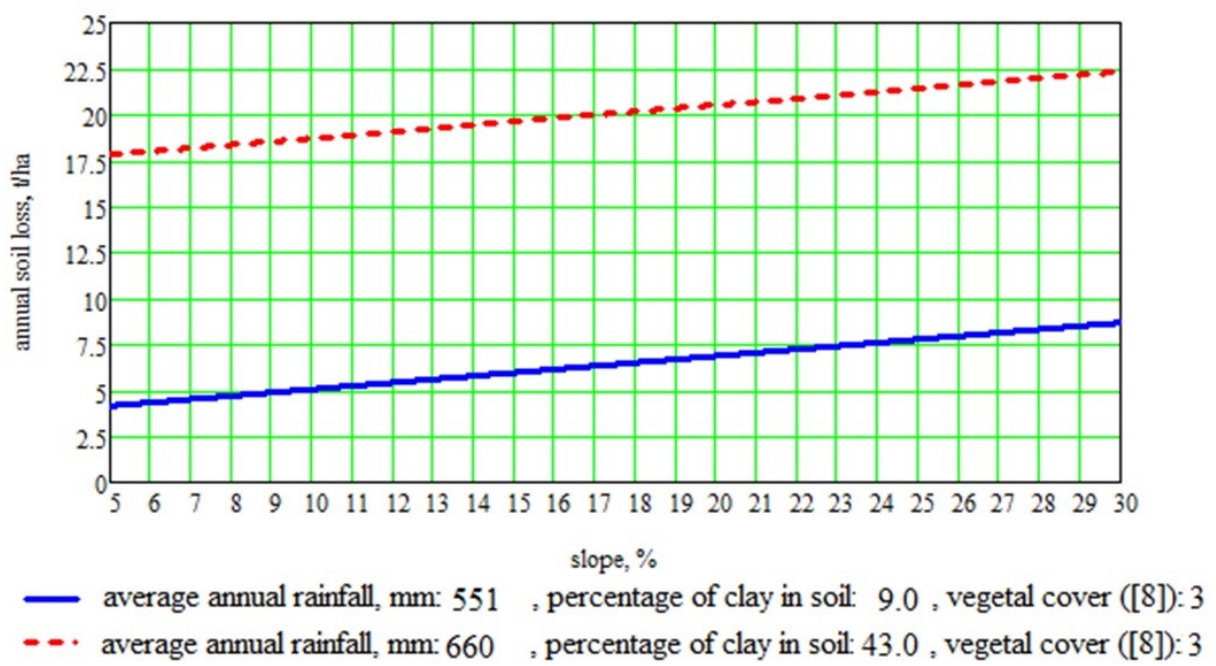

Fig. 4 The annual loss of soil by water erosion, in extreme cases, in the Valea Calugareasca wine area, calculated using formula (1).

\section{Conclusions}

One of the possible explanations for the differences between the estimates of soil quantities lost annually through erosion, over time, is the application of the anti-erosion measures on increasingly larger surfaces (cultivation of slope surfaces on level lines, terraces, complex vegetal coverings, landscaping walls, slope support or anchoring).

Another explanation is the modification in time of the soil structure: texture, composition, natural regeneration capacity, etc. The compacting of the soil increases the resistance to erosion, and these phenomena have increased naturally, but also due to the excessive mechanized intensive exploitation.

Certainly, we cannot ask the problem of the inaccuracy of procedure or method, as long as we do not take into account the natural changes produced in the components of the analyzed process. I refer here to a series of natural processes that take place in the soil, listed above, and which should be taken into account in the calculation and measurements made to estimate the intensity of soil erosion.

For the above reasons, when re-evaluating the erosion intensity in an area, it will start from the updated values of the factors that influence the process. For example, after each soil work, its erodibility should be recalculated, seasonal change of vegetation should be considered, etc. Given these evolutions of influencing factors, soil erosion loss estimates should be revised from season to season or even more often. An extension of the tools and methods of calculating soil erosion losses to a dynamic form should take into account the dynamic characteristics of the factors involved in the process. The long-term monitoring process would be a solution for developing a dynamic model of the erosion process, capable of giving long-term predictions. An initial attempt, in this regard, was made by the authors.

It is possible that, to study the dynamics of soil erosion, it may be necessary to switch to an intrinsic independent variable of the process, which replaces time, because it is not the time the factor that produces the erosion, but the factors involved in the process: precipitation, wind, also may be temperature, etc. 
A possible candidate for the intrinsic parameter as the independent variable of the erosion process would be, the total variation of the soil layer thickness (this is an increasing monotone function, but not linear in general), the total variation of a function, for example. The total variation of the amount of rain and / or of the wind flow could be considered as an intrinsic parameter of the erosion process. Due to the collaboration of these physical factors in the erosion process, only one characterization parameter may not be sufficient for this process, two or more such parameters may be needed. It is also important to study the possible correlations between the influential parameters (factors) of the erosion process, considered in its various mathematical models, to avoid the use as independent variables of some dependent factors.

\section{References}

1. M. Motoc, Fl. Trasculescu, Eroziunea solului pe terenurile agricole si combaterea ei, Ministerul Agriculturii si Silviculturii, Editura Agro-Silvica de Stat, (1959)

2. I. Ionita, Material Prezentare Conferinta, Universitatea Al. I. Cuza Iasi, http://www.unserboden.at/files/dlt2011_13.pdf, (2011)

3. R. Sfiru, P. Cardei, V. Muraru, V. Herea, Methods and techniques of drawing up risk maps for surface rain erosion phenomenon, INMATEH - Agricultural Engineering, pp. $35-42,2 /(2010)$

4. https://esdac.jrc.ec.europa.eu/themes/indicators-soil-erosion

5. P. Panagos, P. Borrelli, J. Poesen, C. Ballabio, E. Lugato, K. Meusburger, L. Montanarella, C. Alewell, The new assessment of soil loss by water erosion in Europe, Environmental Science \& Policy, 54: 438-447. DOI: 10.1016/j.envsci.2015.08.01, (2015)

6. P. Panagos, A. Imeson, K. Meusburger, P. Borrelli, J. Poesen, C. Alewell. Soil Conservation in Europe: Wish or Reality?, Land Degradation and Development, 27 (6): 1547-1551, 2(2016)

7. https://esdac.jrc.ec.europa.eu/Library/Data/EIONET/Meeting032009/country/Romania. pdf

8. U. C. Sharma, V. Sharma, Mathematical model for predicting soil erosion by flowing water in ungauged watersheds, Erosion Prediction in Unguaged Basins:Integrating Methods and Thechniques, Proceedings of symposium HSO held during IUGG2003, Sapporo,July 2003, IAHS Publ. No. 279, (2003)

9. ICDVV, Elaborarea tehnologiilor vitivinicole adaptate pentru diminuarea efectului perturbator al schimbarilor climatice, proiect sectorial ADER 2020, (2011) http://www.madr.ro/attachments/article/117/ICDVV-Valea\%20Calugaresca-ADER116.pdf

10. https://www.onvpv.ro/sites/default/files/pdfs/caiet_de_sarcini_doc_dealu_mare_271ro. pdf

11. Y. Li, X. Bai, Y. Tian, G. Luo, Review and Future Research Directions about Major Monitoring Method of Soil Erosion, 2017 International Conference on Environmental and Energy Engineering (IC3E 2017), IOP Conf. Series: Earth and Environmental Science 63 (2017)

12. A. Lup, L. Miron, I. Alim, Soil Erosion in Romanian Agriculture, Lucrari Stiintifice Universitatea din Iasi, 60(2) (2017)

13. D. Gadone, Stanchi S., Soil erosion Issues in Agriculture, IntechOpen, (2011) 
14. D. Bucur, J. Gerard, A. Costica, ASoil Erosion Control on Arable Landsfrom NorthEast Romania, Soil Erosion in Agriculture, IntechOpen, (2011)

15. R. Blanchard, L. Farrell, Guide to Sources for Agricultural and Biological Research, University of California Press, (1981)

16. C.A. Eftene, S. Dumitru, A. Manea, D. Raducu, A Review of the Impacts of soil sealing on Soil Properties in Romania, SGEM2016 Conference Proceedings, 2, (2016)

17. M. Sevastel, N. Petrescu, M. Musat, Sarbu N., Soil erosion and conservation in Romania - some figures, facts and its impact on environment, Annals: Food Science and Technology, 11, (2010)

18. https://ec.europa.eu/eurostat/statistics-explained/index.php/Agrienvironmental_indicator_-_soil_erosion 